\title{
A SCIDIA CLAVATA.
}

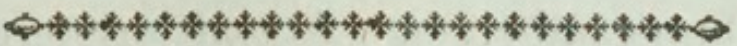

\section{CHARACTER GENERICUS.}

Corpus fixum, teretiufculum, vaginans. Apertura binæ utplurimum ad fummitatem: altera humiliore.

$$
\text { Gmel. Syft. Nat. p. } 3127 \text {. }
$$

CHARACTER SPECIFICUS, छ̈c.

ASCIDIA ftipite longiffimo, corpore ovato, aperturarum utraque laterali.

ASCIDIA ftipite filiformi, aperturarum utraque laterali.

$$
\text { Lin. Syf. Nat. Gmel. p. } 3127 .
$$

VORTICELLA BOLTENI.

$$
\text { Mant. plant.p. } 55^{2} \text {. }
$$

Bolten epift. de nov. zooph. Hamb. 1771.

Solent, ut plurimum, Afcidiæ faxis, rupibus, aliifque marinis fubftantiis bafi adhærere. Forma iis plerumque oblonga, fuperius craffior. Sunt tamen duæ vel tres fpecies quæ ftipite feu pedunculo longo tubulato inftruuntur, unde oritur inter eas et reliquas congeneres fumma diffimilitudo. Specie- 
rum harum anomalarum præcipua, quæ in tabula depingitur, corpus habet ovato-elongatum, fuperficie paululum exafperata. Augent præterea in certis fpeciminibus hanc fcabritiem varix ferpularum, fertulariarum, aliorumque animalium parafiticorum, ut vocantur, fpecies, quæ corporibus folent adhærere. Sunt in corpore Afcidiæ clavatæ duo foramina, alterum non procul a fummo, alterum longe inferius fitum, limbo feu margine paululum levato circundata, e quibus, fi irritetur, aquam ejaculatur more reliqui generis. Stipes interdum vix octo vel novem unciis brevior, in variis fpeciminibus varie inclinatus, nec in ullis omnino rectus, lævis eft, et fere corpori concolor, fcilicet terreo-fufcus, paululum pallens, interdum rubens. In oceano feptentrionali circa annum millefimum feptingentefimum feptuagefimum primo detecta eft fpecies quam defcripfimus. 



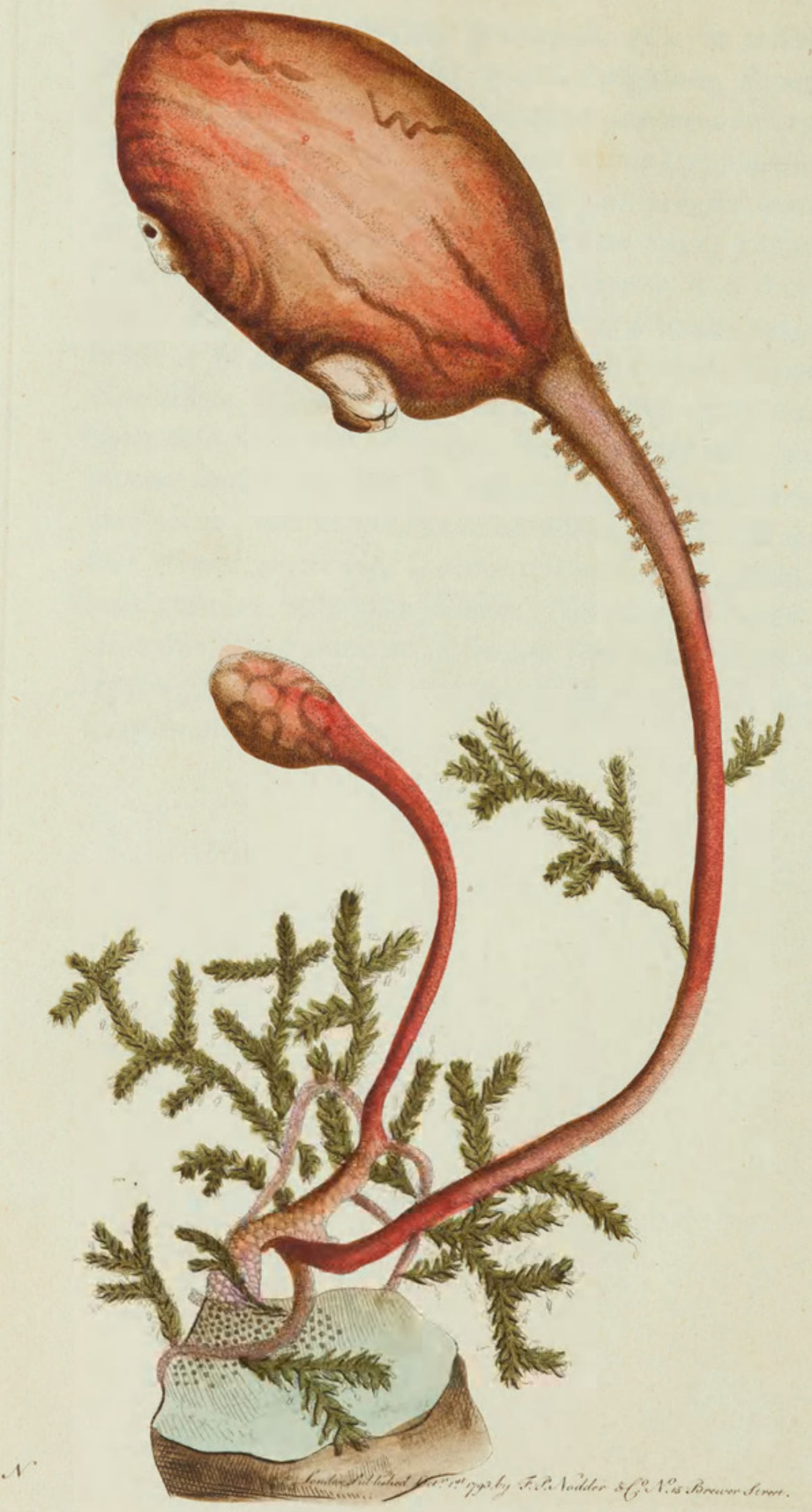




\section{CLAVATE ASCIDIA.}

\section{Q}

GENERIC CHARACTER.

Body fixed, approaching more or lefs to a cylindric fhape; in fome fpecies feffile; in others fupported on a pedicle.

Apertures (in moft fpecies) two: fituated towards the upper part; one lower than the other.

SPECIFIC CHARACTER.

LONG-STALKED ASCIDIA, with elongated oval body and two lateral apertures.

The Afcidix in general adhere by their bafe to rocks, ftones, and other fubmarine fubftances. They are moftly of an oblong form, fomewhat thicker at the upper part than at the lower. There are however two or three fpecies which are furnifhed with a long ftalk, or tubular ftem, which gives them an appearance widely different from the reft of their congeners. Of thefe anomalous fpecies the animal here reprefented is the moft remarkable. The body is of an elongated oval fhape, and of a fomewhat roughened furface: this appearance is alfo in fome fpecimens ftill increafed by various fpecies of ferpulæ, 
pulæ, fertularix, and other parafitical animals, which adhere to it in various parts. The body has two foramina; one feated at a fmall diftance from the upper part, and the other confiderably lower: both are furrounded by a protuberant rim or circle. Through thefe holes, when irritated, it difcharges water, like others of this genus. The ftem is of a very confiderable length; fometimes not lefs than eight or nine inches. It is differently inclined in different fpecimens, and is fcarce ever perfectly ftraight. It is of a fmooth furface, and nearly of the fame colour with the body, viz. a pale earthly brown, and fometimes reddifh. This moft curious animal was firft difcovered about the year 1770 in the Northern Ocean. 


\section{$2 \mathrm{BHL}$ Biodiversity Heritage Library}

Shaw, George. 1793. "Clavate Ascidia, Ascidia clavata [PI. 154]." The Naturalist's Miscellany 5(L), https://doi.org/10.5962/p.310733.

View This Item Online: https://www.biodiversitylibrary.org/item/276340

DOI: https://doi.org/10.5962/p.310733

Permalink: https://www.biodiversitylibrary.org/partpdf/310733

\section{Holding Institution}

Museums Victoria

\section{Sponsored by}

Atlas of Living Australia

\section{Copyright \& Reuse}

Copyright Status: Public domain. The BHL considers that this work is no longer under copyright protection.

This document was created from content at the Biodiversity Heritage Library, the world's largest open access digital library for biodiversity literature and archives. Visit BHL at https://www.biodiversitylibrary.org. 